\title{
Arab Charter on Human Rights \& International Conventions
}

\author{
Junxiang Mao', Ammar Ahmad Ahmad Gady ${ }^{2 *}$ \\ ${ }^{1}$ Human Rights Center, Law School, Central South University, Changsha, China \\ ${ }^{2}$ International Law-Human Rights, Law School, Central South University, Changsha, China \\ Email: tangmao200304@sina.com, ^2565301600@qq.com
}

How to cite this paper: Mao, J. X., \& Gady, A. A. A. (2021). Arab Charter on $\mathrm{Hu}$ man Rights \& International Conventions. Beijing Law Review, 12, 425-446. https://doi.org/10.4236/blr.2021.122024

Received: January 26, 2021

Accepted: May 3, 2021

Published: May 6, 2021

Copyright (C) 2021 by author(s) and Scientific Research Publishing Inc. This work is licensed under the Creative Commons Attribution International License (CC BY 4.0).

http://creativecommons.org/licenses/by/4.0/

\begin{abstract}
This paper will focus on the differences between the basic of the Arab Charter on Human Rights and the framework for its relationship with the United Nations Instruments on Human Rights. This charter represents the Islamic religion approach for human rights (Islamic law, also known as Sharia law). These differences explored whether or not there is a compatible between them and whether the Muslim States can comply Arab Charter on Human Rights while still adhering to Islamic law. Although there are some differences in applying human rights, that does not create a general state of dissonance between Islamic law and international human rights law like the death penalty, religious freedom, and equality between man and woman. Many Jurists and western researchers insist that Islamic law opposes or conflicts with international conventions on human rights. It is argued that the differences would be easier to address if the concept of human rights were positively established from within the themes of Islamic law rather than imposing it as a concept alien to Islamic law.
\end{abstract}

\section{Keywords}

Human Rights, Death Penalty, Religious Freedom, Women Rights

\section{Introduction}

\subsection{Purpose and Methodology}

The League of Arab States has adopted the Arab Charter on Human Rights on 22 May 2004 to affirm the principles contained in (U.N Charter, Universal Declaration of Human Rights, and other international covenants on human rights), which adopts the protection of fundamental rights, including the right to life, the right to freedom of religion, and equality of rights between men and women. On the 
other hand, this chart represents the Islamic religion's principles on human rights, as it is the religion of most Arab countries. Islamic law has affirmed the protection of fundamental human rights for more than 14 centuries that had occurred, such as slavery, murder, and the most extreme form of oppression against women. However, Islamic law allowed and gives exceptions such as the application of the death penalty to those who violate the right to life, the application of the death penalty for apostasy, and the necessity of wearing the veil for women, along with the positive treatment of women due to their differences with men, as a result of women's inherent differences in physical, mental, emotional, and psychological qualities. However, most western scholars, if not all, criticize and condemn some Arab countries' insistence on implementing these provisions, which in their opinion contradict all provisions of international human rights instruments. As a result of the cultural and religious diversity of the world's peoples, human rights can only be protected and promoted through the compatibility of these diversities with constructive international dialogue and cooperation. Muslims represent approximately 1.907 billion of the world's population. Therefore, several questions arise: What are the main differences between the Arab Charter on Human Rights and the international human rights instruments? What role do the Arab charter and international human rights instruments play in protecting freedom of belief and religion? Why do the Islamic religion's rulings insist on applying the death penalty, and have this punishment been abolished in some countries? Why are women treated differently in Arab countries from international human rights instruments? What are the main gaps between Islamic religious rulings and international human rights instruments on gender equality? This paper attempts to answer these questions while also clarifying the position of Arab states on protecting some human rights. This paper will depend on a theoretical study using different references from multiple books (internationals books and Islamic books) and publications previously to explore whether or not there is a compatible and whether Arab countries can comply with international human rights instruments while they still adhere to Islamic law. Section 1 explains the right to freedom of religion in the Arab charter and international human rights instruments, Section 2 clarifies the Arab States' position on the death penalty; Section 3 highlights the primary forms of gender discrimination in the Arab countries.

\subsection{Background}

The Council of Arab League held a meeting in Beirut in 1968 to establish a permanent Arab Commission and asked the Commission to prepare a Charter on Human Rights for Arab countries. In 1990, the Commission brought an Arab Convention on Human Rights to promote the idea of human rights in Arab states, but it took some more years to adopt the first version of the Arab Charter on Human Rights. Therefore, in 1994, the League of Arab States adopted the first version of the Arab Charter on Human Rights at its $50^{\text {th }}$ anniversary. Al-Midan (2007: p. 147) argued that "The adoption of the Charter symbolized the impor- 
tance of respect for human rights both to the Arab world and the League". The Charter consisted of 43 articles with the preamble. That charter proclaims essentially the same rights as those have adopted in the other international and regional human rights instruments. However, the Charter of the League has criticized includes the charter did not contain any human rights enforcement mechanism, particularly in comparison with the other regional human rights instruments such as the mechanisms within the European and American Conventions on Human Rights and the African Charter on Human and People's Rights. Several meetings and conferences were held in Europe and some Arab countries to urge states to amend the charter. Ghormade (2012: p. 1) explained that "in 2002, the Council of the League of Arab States adopted resolutions to modernize the Charter of 1994". In January 2004, Arab Commission on Human Rights invited all Arab countries to submit their observations and proposals to improve the charter, with a promise that the Commission would examine the charter again, before that year the High Commissioner for Human Rights invited many Arab experts for a meeting in Cairo in December 2003 to present and discuss proposals to improve the charter. In the $16^{\text {th }}$ regular session of the Arab summit, which holds on 23 May 2004 in Tunis, the new version of the Charter war adopted. On 15 March 2008 the charter entered into force after ratification by seven countries such as; Jordan, the United Arab Emirates, Bahrain, Algeria, Palestine, Libya, and Syria. It was later ratified by Qatar, Lebanon, Saudi Arabia, and Yemen on the new version of the Arab charter. This Charter on Human Rights is now a binding treaty reflecting the demands and aspirations of the Arab peoples and reflects their desire for a meaningful and enforceable human rights system in their region. This charter contains a preamble and 53 articles that affirm the U.N Charter's principles, the Universal Declaration of Human Rights (UDHR), the International Covenants on Human Rights, and the Cairo Declaration on Human Rights (1990). However, western scholars insist this charter represents Islam's fundamental principles on human rights that are opposing and conflict with all international conventions on human rights, particularly in; religious freedom, the death penalty, and equality between man and woman.

\section{The Right to Freedom of Religion}

All conventions, whether international or regional, affirm that every person has the right to freedom of religion, and should be treated equally in dignity, enjoy rights without distinction of any kind such as race, color, sex, language, religion, political or other opinions (whether national or social in origin national), property, birth or other statuses (UDHR, 1948). In contrast, Islam contained a guideline on these types of rights, and most importantly, the right to freedom of religion which is one of the many fundamental principles of Islam, states that a person is free to adopt any form of belief he desires. Freedom of religion is now generally accepted and guaranteed through national, regional, and international laws, but there is a conflict or difference between international conventions and 
Islamic law (the Arab charter) on the freedom to change religion or belief.

\subsection{International Law}

After the suffering of discrimination that existed among individuals because of religiosity and other kinds of rights, all international conventions have been adopted to affirm that every person has the right to freedom of religion. For instance; article 18 of the Universal Declaration of Human Rights affirmed many rights related to freedom of religion, such as the right to freedom of thought, conscience, and religion, the freedom of a person to change his religion or belief, freedom to manifest his religion or belief in teaching, practice, worship, and observance, either alone or in community with others (in public or private) (UDHR, 1948). Article 18-2 of the International Covenant on Civil and Political Rights (ICCPR) has affirmed that "No one shall be subject to coercion which would impair his freedom to have or to adopt a religion or belief of his choice." This Covenant also obligated state parties to respect and protect the right to practice and educate, including parents and legal guardians' right to ensure their children's religious and moral education following their convictions (International Covenant on Civil and Political Rights, 1966). Nevertheless, this Article has faced opposition from Muslim countries. Partsch (1981: p. 207) confirmed "some of Arab countries such as Saudi Arabia, Yemen, and Afghanistan, have pressed for deletion of the right of freedom to change religion or belief due to the principles s of Islamic law. Islamic law prohibits a person's freedom to change religion". Instead of a complete deletion, a compromise has been reached in changing the language to this right. Adebayo (2001: p. 158) also confirmed that "member states have been reached to include the freedom to convert or adopt a religion or belief of (ones) choice". Article 27 from the same Covenant (ICCPR) provide as an essential provision "In those states in which ethnic, religious or linguistic minorities exist, persons belonging to such minorities shall not be denied the right, in community with the other members of their group, to enjoy their own culture, to profess and practice their religion, or to use their language." Article 2 of the Declaration on the Elimination of All Forms of Intolerance and Discrimination Based on Religion or Belief has also stressed "the right to freedom of thought, conscience and religion apply equally to all people, regardless of their religions or beliefs and without any discrimination as to their equal protection by the law." However, all these conventions did not give absolute freedom to exercise this right but rather gave states the right to set restrictions and limitations. These restrictions and limitations should be prescribed by law or are necessary to protect public safety, order, health or morals or the fundamental rights and freedoms of others, with non-discriminatory between individuals, as these limitations can apply in a manner that does not vitiate the right to freedom of thought, conscience, and religion.

Moreover, some regional conventions have also reaffirmed this right for every person. For instance, Article 3 of the American Declaration of the Rights and 
Duties affirmed "every person has the right freely to profess, manifest and practice in public and private places with the duty of every person to cooperate with the state authority and the community to respect the social security and welfare, following his ability and existing circumstances." Article 8 of the African Charter on Human and People's Rights also provided that "the freedom of conscience, the profession and free practice of religion shall be guaranteed and no one may, subject to law and order, be submitted to measures restricting the exercise of these freedoms." The Charter of Fundamental Rights of the European Union affirmed that everyone has the right to freedom of thought, conscience, and religion, includes freedom to change religion or belief and freedom, either alone or in community with others and in public or in private also has the right to manifest religion or belief, in worship, teaching, practice, and observance. Consequently, there is an acceptance in modern society and agreement with the basic notion of the right to freedom of thought, conscience, and religion as mentioned because the right to freedom of religion consider as one of the fundamental principles of a democratic society.

\subsection{Apostasy in Islamic law}

We noted that all international conventions give individuals the right to practice their religion in private or public and give them the right to change their religion. Eltayeb \& Mohamed (2001: p. 55) explained that "Article 18 of ICCPR has faced the challenge of a coalition led by Saudi Arabia with South Africa and six other socialist countries that abstained from ratifying this right". This provision is the reason that pushed some Islamic countries to express their opposition which is incompatible with the provisions of Islamic law. Ghormade (2012: p. 1) confirmed that "Arab Charter is a typically different kind of documents based on the dual combination of the supremacy of Qur'an values and contemporary norms of human rights, which are reflected in international covenants". Therefore, the League of Arab has adopted this charter to assert the Holy Qur'an provisions and the other similar instruments that do not have any conflict with the Islamic Law (Sharia). According to the Quran, there shall be no coercion in [acceptance of] the faith (Islam Holy Qur'an) ${ }^{1}$. The principle of non-compulsion in religion is one of the fundamental principles in Islam, where non-Muslim minorities in Muslim countries have the right to freedom of thought, conscience without limitations nor restrictions to practice their religious except as confirmed by international conventions. Islam has prescribed some limitations that are necessary to protect public safety, order, health or morals, or the other fundamental rights, which there is no prohibition or punishment to convert any religion, as one of Islam's fundamental principles is, to tell the truth, whoever wishes to believe should do so, and whoever wishes to disbelieve should do so (Islam Holy Qur'an)2. This freedom had declared by the Prophet Mohammad in

${ }^{1}$ Holy Qur'an, Surah Al-Baqarah, Verse (256).

${ }^{2}$ Holy Qur'an, Surah Al-Kahf, Verse (29). 
the first Constitution for the Islamic State when he admitted to the Jews that they, with Muslims, are one nation ${ }^{3}$.

On the other hand, Islam has guaranteed the freedom of discussion between religious followers on good instruction and best way without any bickering and derision from each other's during the dialogue or debate between Muslims and non-Muslims, if all of them did not reach any result or agreement, then everyone has the right to follow what he or she has chosen (Islam Holy Qur'an)4. Article 30 of the Arab Charter has given everyone the right to freedom of thought, conscience, religion and announced no restrictions could be imposed on the exercise of such freedoms except what has been provided by law and without discrimination between individuals. Islamic law has explained why forgiven such freedom because of the coercion in the religion is cancel of will also the choice and domination of corruption, bloodshed, injustice and killing humanity, it is more severe than killing. As a result, no one can be forced or coerced to convert or believe in Islam, according to Islamic values. All of these conventions, treaties, and Islam religion have the same opinions on giving every person the right to choose the religion. However, the point of conflict between them is about the right of freedom person to change religion. Natan (2000: p. 85) argued "some Muslim scholars think these conventions inconsistent with the Islamic Law because Islamic religion forbids the individual believer in God (Allah) to change their religion and to convert or believe from Islam to any other religion which this act will be seen as treason". The person who betrayed God (Allah), the Islamic religion will consider him as an apostate and will apply or faces severe social, legal sanctions in many Islamic states. Alalwani (2012: p. 785) has defined "The term apostasy (in Arabic: Al-Riddah) returns to something one had left from something one had reached, which means abandonment or renouncing religious faith".

Furthermore, while the freedom of change or convert to another religion considers as one of the fundamental rights in international conventions and treaties, some Muslim scholars consider this right a betrayal in their opinion. The apostasy in Islam religion is one reason for the betrayal that is causing the death penalty. The apostasy is not just betrayed God and Islam religion but also betrayed their nation, family, friends, ethnic group, team, and social. As with any legislation globally, Islam has declared severe sanctions for the traitor or apostate ${ }^{5}$. According to some Islamic scholars, apostasy may be one of three things such as; by the thoughts of the heart, words spoken, and deeds, the apostasy of the heart will be in doing any action that might indicate disbelief in God (Allah) like anything can sharing the worship between God and other creature (Jesus Christ and

${ }^{3} \mathrm{Al}-\mathrm{Medina}$ city is located in Saudi Arabia which was the capital city for Islam religion.

${ }^{4}$ Holy Qur'an, Surah Al-Kafirun, Verse (6).

${ }^{5}$ The word "traitor" may also be used to describe a person who betrays (or is accused of betraying) their own political party, nation, family, friends, ethnic group, team, religion, social class, or other group to which they may belong. Often, such accusations are controversial and disputed, as the person may not identify with the group of which they are a member, or may otherwise disagree with the group leaders making the charge. See, for example, race traitor. 
the Holy Spirit). The apostasy of the tongue would be by any words that indicate the denying that God (Allah) as the creator, also questioning the existence of God or insults to Islam and by serious infractions (praying to idols). The apostasy of deeds would be by refusing or reciting some Muslims obligations such as reject the obligations of the money (Zakah) and praying five times a day ${ }^{6}$. Although Holy Qur'an did not mention the punishment for apostasy, however, most of the Qur'anic references deal with how God (Allah) looks to the apostate, how he will punish him in the day of judgment (in the last day). Therefore, some traditional Islamic law enforces harsh penalties for apostasy under Islamic criminal law rules, including the death penalty for men and life imprisonment for women. At the same time, some schools of Muslim jurisprudence like Shafii, Maliki, and Hanbali their opinion are women should be punished as they punish the man, but Hanafi's opinion is more lenient which they are permitting a woman to serve out her sentence through life in prison until she either comes to repentance or dies.

On the other hand, Islamic religion may forgive a few types of actions that are not considered a rejecting of faith, such as ignorant mistakes, misunderstandings about Islamic Law, and the cases coercion to abandon Islam. Therefore, the person who did the act would not be guilty of apostasy because the punishment is a statement only in situations where the Muslim talked about the true feelings in his heart. Although Islamic religion has set the punishment for apostasy, it has also set several conditions to apply it. For instance, Islam obliged the apostate to be an adult, which means the apostate should be an adult and reach the age under legal accountability, which there is no punishment against children ${ }^{7}$. The awareness between the harmful things or the valuable things means no punishment in Islamic law can apply against any person who is crazy or in a coma, which means the apostate should have a wide choice to choose to leave Islamic religion and convert to another religion with complete freedom. Before applying such this penalty, Islam obliged the states to allow apostate to express his or her repentance (in Arabic: Al-Taubah) and should give time, at least three days, to discuss the reasons that pushed him to apostasy, also to persuade him to reverse his decision and return to Islam ${ }^{8}$.

However, there is another opinion among Muslim scholars that says everyone has the right to change their religion because there is no clear evidence of rejecting the right to change religion, because God (Allah) threatened who change their religion on the afterlife and the duties for Muslims are just telling the truth and introducing Islam to them. Therefore, there is no force or coercion for any person to convert or believe in Islam.

\footnotetext{
${ }^{6}$ Available at: http://www.islamreview.com/articles/apostasy in Islam.

${ }^{7}$ Usually, the legal age of accountability in all legislation to reach the age of 18 years.

${ }^{8}$ There is some opinion from the modern scholar Muslims about the death penalty of apostasy which they are argue that Holy Qur'an did not mention like this punishment for example see, Hadrat Mirza Tahir Ahmad Khalifatul Masih IV-The Truth about The Alleged Punishment for Apostasy in Islam-2005.
} 


\section{The Death Penalty}

All international conventions emphasize individuals' right to life, including Islamic religion, as every person has the right to life and the right to protect his life from any violations. States have formulated a severe social and legal sanction to protect this right due to its importance. This part attempts to explain the international community perspective and Arab Charter (Islam law) on the death penalty. Simultaneously, some western scholars characterize Islamic law as an extremist doctrine and different from other legislation in the death penalty, where the international community aims to abolish the death penalty.

\subsection{Toward Abolition of the Death Penalty}

The international community worked for a long time to draft and adopted many international conventions to safeguard and guarantee human rights violated during world wars and to persuade all states to join and ratify these conventions. They started to assert that everyone has the right to life and formulated in the Universal Declaration of Human Rights, which is considered as the fundamental of international human rights bill, according to Article 3 of the Declaration that states "Everyone has the right to life, liberty and security of person." Article 6 of the International Covenant on Civil and Political Rights also states that "every human being has the inherent right to life and this right shall be protected by law as well as no one shall be arbitrarily deprived of his life." This Article considers the basis point to start abolishing the death penalty, which only ten countries have abolished this penalty (IBAHRI Resolution, 2008). Hood (2006: p. 2) has mentioned "states parties to the U.N have held an extensive discussion to restrict the death penalty and obtain a place under this Covenant, thus defining the conditions for countries that have not yet abolished the death penalty". Under Article 6 of the Covenant, which established some restrictions or limitations to apply this sanction? For instance; this sanction shall apply in the case of the most severe crimes according to the law in force at the time of the Commission of the crime and under a final judgment rendered by a competent court; this Article not only has restricted the death penalty but also gave the right to seeking pardon for any person been sentenced to death. It is prohibited to apply this penalty to anyone under the age of 18 and a pregnant woman until put her delivery or a nursing mother within two years from the date of her delivery. Although this Article has placed some restrictions on the application of the death penalty, this Article did not explain the meaning of "most serious crimes," which led to a difference in the application due to the difference between countries according to their national culture, religion, traditions and political contexts. General Assembly (G.A.) has adopted the Second Optional Protocol of ICCPR, which aims to abolition the death penalty' this protocol contains 11 articles. According to Article 1-2 that declared explicitly to each State Party shall take all necessary measures to abolish the death penalty within its jurisdiction, and the states parties to the present protocol shall include or attach in the reports information on the 
measures that they have adopted to give effect to the present protocol.

However, this protocol gave an exception to the states parties of the ICCPR and the second optional protocol, the right to make a reservation in the time of ratification or accession that provides for the application of the death penalty in time of war according to a conviction for a most serious crime of a military nature committed during wartime $e^{9}$. This protocol still allowing the states parties to apply the death penalty during the time of war, as this time constitutes a sensitive time because, during this time, many violations will occur against civilian people, particularly in the absence of the judiciary system, which the majority of people need in order to protect their right to life ${ }^{10}$. Many people (civilian casualties) die during a battle, and the prisoners of war are disposed of under the terms of committing the most severe military crime. Furthermore, the regional conventions also convinced their state parties to abolish the death penalty. For instance, the European Convention for the Protection of Human Rights and Fundamental Freedoms has confirmed the right to life as an essential value in a democratic society. Therefore, abolishing the death penalty is essential for protecting this right and for the full recognition of all human beings' inherent dignity. Article 1 from the same protocol explicitly declared the abolition of the death penalty "The death penalty shall be abolished. No one shall be condemned to such penalty or executed"11. Article 1 of the Protocol to the American Convention on Human Rights to abolition the death penalty has also abolished the death penalty and provides that "The States Parties to this Protocol shall not apply the death penalty in their territory to any person subject to their jurisdiction."

Through these conventions and the different protocols, we can find a trend between some states to increase the death penalty restrictions with a view toward abolition, as these restrictions will become an international custom, especially in those who already ratified the abolition. Although most countries have ratified all international treaties aiming to abolish the death penalty, the penalty still applies by most of these countries that are parties in this protocol and from the countries that did not abolish the death penalty or sentence of death. Their justifications, they are imposing such this penalty just for the most severe crimes (war crimes) under the law in force at the time of the Commission of the crime and not contrary to the provisions of the present Covenant and the Convention

\footnotetext{
${ }^{9}$ Article 2 of the second Optional Protocol to the International Covenant on Civil and Political Rights, aiming at the abolition of the death penalty.

${ }^{10}$ It should be mention that every country has legislation against the crime of treason which they set the severe social and legal sanctions for this crime (death penalty) such as Australia, Brazil, Canada, France, Germany, Italy, New Zealand, Russia, United Kingdom, United States.

${ }^{11}$ All Council of Europe member states have ratified Protocol 13. Armenia has signed but not ratified the protocol. Russia and Azerbaijan have not signed it, beside this regional protocol there are other protocols have issued to forbid the death penalty such as Protocol number 6 to the European Convention for the Protection of Human Rights and Fundamental Freedoms, Others strictly limit the death penalty, including: The Convention on Human Rights and Fundamental Freedoms of the Commonwealth of Independent States, the American Convention on Human Rights and the Arab Charter on Human Rights.
} 
on the Prevention and Punishment of the Crime of Genocide (The Amnesty International Reports).

\subsection{The Death Penalty in Arab Charter and Islamic Law}

\subsubsection{Arab Charter}

The Arab Charter on Human Rights (2004), like any other human rights bills, has stressed the right to life, declaring in Article 5 that every human being has the right to life inherently and that this right (right to life) must be protected by law, with no arbitrary deprivation of life permitted. However, this right is not absolute, which means that laws may deprive a person of their liberty. On the other hand, it has established specific strict controls (restrictions) and limitations to apply, such as this sentenced, according to Article 6 of this Charter, it can be imposed only for the most severe crimes and must be applied under the laws in force at the time. Nevertheless, the person who was sentenced to the death penalty has the right to seek pardon or commutation of the sentence, and this severe crime can be determined based on the domestic legal system. Article 7 also prohibits the death sentence on persons below 18 years of age and also prohibited for a pregnant woman before her delivery or on a nursing mother within two years from the date of her delivery; in all cases, the best interests of the infant shall be the primary consideration and because most of the Arab countries believe in Islam. They are following Islamic law and its position, especially in the case of the death penalty.

\subsubsection{The Perspective of Islamic Law on the Death Penalty}

All religions adhere to the sanctity of life and seek to protect this right from any infringement; they have allowed the death penalty to be used under strict conditions. Braybrooke argued that "all religions have allowed the death penalty to be used under strict conditions and the imposition of human life respect". As it was declared, Islamic law came to protect the five necessities of life that people cannot live without these rights (e.g., preservation of the divine religion, preservation of the self, preservation of the mind, preservation of honor and lineage, preservation of wealth). As a result, Islamic law imposes the harshest sentences on those who violate these rights, including the death penalty. This penalty is not absolute, where Islamic law has established a strict regulation over how it is applied, similar to other legislations. Ghassemi (2009) explained that "the debates between Muslim scholars and many Western scholars about the Islamic world's penal policies and procedures vary from those of other countries in terms of ideology and philosophy".

\section{A. Types of criminal penalties in Islamic law}

Corporal punishment is a common punishment in Islamic societies where the penal policies and procedures are generally allowed and legitimized by Islamic Sharia. In Islamic law, the sentences are divided into three categories based on the nature of the offense: divine punishments (Hudud), Law of Equality (Qisas), and arbitrary punishments (Ta'zir). 


\section{- Divine Punishments (Hudud)}

The first type of penalty is divine punishments (Hudud) derives its authority from Qur'an and the Prophet Muhammad's explanations, as these punishments have been defined by God (Allah) in the Qur'an, which is God's exclusive rights. As a result, individuals cannot waive their rights to tolerance and even reconciliation in the face of these sanctions. This type of punishment can be extended to many crimes that can include the death penalty, lashes, or cutting a portion of the body (the hands). For instance, 1) Sexual slander (Qazf) is when someone accuses someone of adultery or sodomy. The penalty is 100 lashes, and it applies to someone who accuses someone of adultery without providing proof of his words' sincerity. 2) The penalty for drinking alcohol (shurb al-khamr) is 40 lashes for any person who does so. 3) The rebellion and corruption on earth (Muharib); this type of crime will be punished differently depending on the outcome of the offense, Islam law differentiated between three types of results: a) Criminal robbed money without killing anybody; he will be punished by having a part of his body cut off (the hand). b) Criminal has stolen the money and killed people; he will be punished by having the death penalty.

4) The penalty for adultery (Zina); the punishment depends on the offender (whether persons single or married): a) Unmarried persons are those who have never been married in a legal marriage and who are free and responsible adults. The penalty will be 100 lashes (Islam Holy Qur'an) ${ }^{12}$. In addition to this penalty, the person should be barred from returning to his homeland for a year (Imprisonment). b) Married person means the person who had intercourse within the bounds of legal marriage where the person should be free and adult. The penalty will be death by stoning. Islam distinguished between single and married people in retribution because unmarried people may be unable to marry; their marriage may have been postponed due to financial difficulties (lack of funds), in contrast to married people who have no excuse to take such action as well as to maintain the family bond between husbands and wives (also the children) ${ }^{13}$. Therefore, to protect people's symptoms and dignity, Islamic law has emphasized the application of such punishment, stating that in all cases, people must bring witnesses to the occurrence of the act, and their testimony must be identical; otherwise, if there is a minor violation of this condition or doubt, the punishment of false testimony would be applied (Islam Holy Qur'an) ${ }^{14}$.

\section{- Law of Equality (Qisas)}

The second form of penalties is the Law of Equality (Qisas), which punishes crimes involving taking life or causing bodily harm; the penalty will be by retaliation or blood money (al-diya). Ali Mohamed (2012: p. 1) has identified "this type of punishment is an exclusive right to God, but the individuals can apply it

\footnotetext{
${ }^{12}$ Holy Qur'an, Surah An-Nur, Verse (2).

${ }^{13}$ There are imaginary numbers indicate the reasons for disintegration of the family including illegal relations after marriage and the main victims as a result of this crime are the children _ the number of homeless children continues to increase.

${ }^{14}$ Holy Qur'an, Surah An-Nur, Verse (4).
} 
where they can waive or tolerate and reconcile them". The application of this penalty should be equivalent to the crime's result, which means that if the crime was murder, the punishment would be the death penalty. If the crime was not murder and it was a loss of a limb from the body, the punishment would be similar (Islam Holy Qur'an) ${ }^{15}$. However, the act of Qisas (Law of Equality) must be proportionate with the injury to the victim and not excessive of it in any way (The Higher Education Academic, 2011). Islamic law has emphasized the right to life, so, Islam forbids the killing between people and forbids to violate this right which it is put the severest penalties for those who violate this right and apply similar sanction (the death penalty) in order to preserve the soul and maintain dignity and to be a deterrent for anyone he or she intends or think to kill any human being (Islam Holy Qur'an) ${ }^{16}$.

Furthermore, while the offender can face the death penalty, Islamic law has stressed that it divides murder crimes according to the offender's intention during its implementation. This division aims to give the offender the right to seek pardon, which means that if the offender is used to murdering or has judicial precedents, he will not give the right to seek pardon, and therefore the murder in this case.

\subsection{Intentional Killing or Homicide (Qatl Al-Amd)}

Muslim scholars define a crime of intentional killing or homicide as person kills another unjustly. Al-Sharafi (2005: p. 140) defined the intentional killing”a person kills another (infallible blood) unjustly by a machine that can kill predominantly by the evidence (two witnesses) or confession the offender". In this situation, the death penalty will be applied; however, the offender will have the right to demand a pardon and have his sentence reduced if the victim's family agrees to forgive him and accept blood money instead of the rule of equality. Islamic law usually pushing people (victim relatives) to forgive the offender and take blood money or forgive the offender without taking anything. Before applying this punishment, it is necessary to have some critical conditions set by Islamic law, such as:

1) Murderers must be adults and have an intention to kill another person (this sanction shall not be imposed on persons under 18 years of age).

2) Murderers should not do a kind performance of duty or self-defense (doing public duties, protecting oneself, property, family, mind, and religion), which are well-established basic Islam principles.

3) Murderers must be using a machine that can kill predominantly.

4) The evidence (two witnesses) or confession offender.

\subsection{Killing by Mistake (Qatl Al-khat'a)}

Mistake or the accidental homicide; is killing another (infallible blood) by Mis-

\footnotetext{
${ }^{15}$ Holy Qur'an, Surah Al-Baqarah, Verse (178).

${ }^{16}$ Holy Qur'an, Surah Al-Baqarah, Verse (178-179).
} 
take and using a machine that cannot kill predominantly. The difference between murder by Intentional Killing and Mistake is intention. Killing by Mistake does not have an intention to kill another person. For instance, a person went hunting an animal and by Mistake shoot a person and killed him; in this case, the blood money shall be applied and take the money from the offender or his relatives. If the offender's relatives have no money, then the government (represented by the governor) must pay the blood money instead. In all circumstances, Islamic law considers murder as a mistake that is outside the norm of life (Islam Holy Qur'an ${ }^{17}$. The death penalty will take a long time to apply such this punishment due to ensuring human life, which some Arabic and Islamic penal law has declared that the death penalty shall take the time to pursue the final judgment rendered by a competent court.

\subsection{A Discretionary Punishment (Ta'zir)}

This type of penalty applies in cases there is no specific punishment prescribed by Islamic law; the judge has the authority to inflict such punishment on the offender that is suitable given each particular case's circumstances. Ali Mohamed (2012: p. 237) explained the discretionary punishment "as a corrective punishment lower than (divine punishments), and it becomes applicable in cases that do not incur divine punishments and the law of equality"18.

\section{The Non-Discrimination between Genders}

The international community seeks to protect and promote women's rights and their equality with the rights of men due to what happens to them with many violations in various countries, especially developing countries. Women still suffer from persecution and distinction in all of their rights mentioned in many international treaties and conventions, such as: their inability to exercise some of their political and civil rights, domestic violence, sexual abuse, slavery, and servitude. On the other hand, Western and Arab scholars differ from giving women full freedom without limits and restrictions according to their nature Physicality, such as; her right to full employment opportunities on par with men, her right to inheritance, and her freedom to dress.

\subsection{The Equality between Genders under International Conventions}

Internationally, many international conventions have been adopted to affirm women's rights, such as the Convention on the Elimination of All Forms of Discrimination against Women. According to the preamble of the Charter of the United Nations that affirms the fundamental of human rights in the dignity and worth of the human person and the equality between men and women. Article 1 of the Universal Declaration of Human Rights also declared and affirmed the

\footnotetext{
${ }^{17}$ Holy Qur'an, Surah Al-Nisa, Verse (92).

${ }^{18}$ See Ashgar Ali Ali Mohamed, Ibid, at 237.
} 
equality between man and woman "affirm human beings are born free and equal in dignity and rights where they endowed with reason, conscience and should act towards one another spirit of brotherhood." Both International Covenant on Civil and Political Rights, the International Covenant on Economic, Social, and Cultural Rights prohibit discrimination based on sex and guarantee equality between women and men to enjoy all rights covered by the Covenants (The Higher Committee of Human Rights, 2014). International Covenant on Civil and Political Rights explicitly obligated in Article 3 the states parties undertake to ensure the equal right of men, women and the enjoyment of all civil and political rights outlined in the present Covenant. Article 26 from the same Covenant has laid the principle of the equality between man and woman before the law without any discrimination "the law shall prohibit any discrimination and guarantee to all persons equal and effective protection against the discrimination on any ground such as race, color, sex, language, religion, political or other opinion, national or social origin, property, birth or other status articles." Article 3 of the International Covenant on Economic, Social, and Cultural Rights makes it a duty for all states parties of Covenant to undertake and ensure the equal right of men and women to the enjoyment of all economic, social, and cultural rights outlined in this Covenant.

Moreover, to confirm the prohibition of the discrimination between man and woman, the General Assembly of the United Nations adopted the Convention on the Elimination of all Forms of Discrimination against Women on 18 December 1979, entered into force on 3 September 1981. This Convention has a preamble and thirty articles requiring state parties to condemn all forms of discrimination against women and adopt appropriate legislative and other measures to prohibit all forms of discrimination against women. It also requires state parties to take all appropriate measures to change the social and cultural patterns of conduct of men and women to eliminate prejudices and customary based on the idea of the inferiority or the superiority of either sexes or stereotyped roles for men and women ${ }^{19}$. This Convention identified the obligations of states to take all appropriate measures in different fields to eliminate discrimination against women, includes political and public life, also in education. On the other hand, regional conventions affirmed women's rights and equality with men and forbade discrimination between women and $\operatorname{men}^{20}$ (e.g., the European Charter for Equality of Women and Men in Local Life, American Declaration of the Rights and Duties of Man). These conventions affirm that every individual has funda-

\footnotetext{
${ }^{19}$ Aicle (5-a) of the Convention on the Elimination of all Forms of Discrimination against Women.

${ }^{20}$ According to Article 2 of African (Banjul) Charter on Human and Peoples' Rights, every individual shall be entitled to the enjoyment of the rights and freedoms recognized and guaranteed in the present Charter without distinction of any kind such as race, ethnic group, color, sex, language, religion, political or any other opinion, national and social origin, fortune, birth or other status and in another side it affirmed the equal before the law and every individual shall be entitled to equal protection of the law.
} 
mental human rights without distinction of any kind, such as race, color, sex, language, religion, political or other opinion, national or social origin, property, birth, or another status.

\subsection{Women's Rights in the Perspective of Arab Charter and Islamic Law}

The Arab Charter and Islamic Sharia affirm the elimination of all forms of discrimination against women and equality between men and women in various circumstances, except the natural difference between them in physical, mental, emotional, and psychological characteristics, tendencies, and abilities. Therefore, some issues in the Islamic religion (Sharia law) treat men and women as different (positive discrimination).

\subsubsection{Arab Charter on Human Rights}

Article 3 of the Arab Charter on Human Rights guarantee the right of non-discrimination between men and women by providing the right for every individual to enjoy the rights outlined in this charter without any discrimination such as race, color, sex, language, religious belief, opinion, thought, national or social origin, wealth, birth or physical or mental disability. The right of non-discrimination also has a positive dimension where this Article persuaded the states to take the requisite measures to guarantee effective equality in the enjoyment of all the rights and freedoms to ensure the protection against all forms of discrimination based on any of the grounds mentioned above (Ghormade, 2012). The Arab charter does a duty to all State parties to take all the requisite measures to guarantee equal opportunities and effective equality between men and women to enjoy all the rights set out in the charter. It also declared that all persons are equal before the law, and all persons have the right to enjoy its protection without discrimination Arab Charter on human rights (2004).

\subsubsection{The Positive Discrimination for Women under Islamic Law (Sharia)}

In Islamic law, the right to equality between men and women receives much attention; in some cases, it may exceed the men due to women's position in men's lives. Islamic law considers women in general as children (daughters), sisters, wives, and mothers. However, Islamic law treated women as dissimilar with men (positive discrimination) due to their natural differences in physical, mental, emotional, and psychological qualities, inclinations, and abilities, while western scholars consider it discrimination against women, such as:

\section{- Veil (Hijab)}

Islamic law requiring from all Muslim people, whether a person is a man or woman, to fulfill the different requirements related to the parts of the body that should be covered (in Arabic: Satr or Awrah), which is a term used within Islam and denotes to the intimate parts of the body for both men and women, this Awrah must be covered by clothing, and the detection of Awrah is unlawful in 
Islam and regarded as a $\sin ^{21}$. The Prophet Mohammed has prohibited "No man should look at the (Awrah) of another man, and no woman should look at the (Awrah) of another woman." Therefore, Islamic law explained the body parts that every person and woman should cover it (the Awrah) and explain the man's Awrah, which starts from the navel to the knee. The Prophet Mohammed has indicated to the part between the navel to the knee should be covered and said: "The thigh is Awrah." 22 A woman has other provisions compatible with her femininity and body to preserve their honor, dignity as a human being and comply with the divine orders. Islamic Law explained the woman's Awrah, as the woman must cover all her body parts except the face. Islamic law forbids women to detection their beauty (adornment) to other men such as makeup and jewelry due to the attraction of the man to woman, but the women can expose their adornment to their husbands, their fathers, and some of their relative from the husband or their family (husband fathers, husband, sons) (Islam Holy Qur'an) ${ }^{23}$. Therefore, all Muslim persons believe that the Hijab (veil) contributes to the stability and preservation of marriage and family by eliminating the chances of extramarital relationships and protecting the women from the men who are slaves of lust and desire.

In contrast, the Hijab (veil) is one of the Islamic obligations for women should obey. The Prophet's wives and all Muslim women have been ordered to fulfill the requirements of the Hijab by wearing (Jilbab), which is a long outer garment that covers the entire body (Islam Holy Qur'an) ${ }^{24}$. The Prophet Mohammed has explained the part from woman's body that should be covered "O Asma" when a woman reaches the age of menstruation; it does not suit her that she displays her parts of the body except this and this and he pointed to her face and hands." The Hijab is a term used by many Muslim women to describe their head cover, and this may or may not include covering their face. The Arabic word "Hijab" can be translated into the veil, while other meaning for the word "Hijab" is an Islamic dress code include screen, covering, mantle ${ }^{25}$.

\section{- Inheritance}

Many Western scholars and advocates of freedom for women's rights against the inheritance procedures by Islamic law because women get half of what the man gets, as these procedures violate the women's rights in the equality principle. Women are getting half of what the man gets but not in all circumstances, which sometimes the women will get the same as the men get and occasionally will get more than the men get. This part attempts to explain the viewpoint of Islamic law. A woman's inheritance may differ according to the different dues according to the size of her responsibility. For instance, if the woman has broth-

\footnotetext{
${ }^{21}$ Available at:

http://www.islamic-dictionary.tumblr.com/post/5658467793/awrah-arabic-is-a-term-used

${ }^{22}$ Narrated-Al Tirmidhi from Ibn Abbas (may Allah be pleased with him).

${ }^{23}$ Holy Qur'an, Surah Al-Nur, Verse (39).

${ }^{24}$ Holy Qur'an, Surah Al-Ahzab, Verse(59).

${ }^{25}$ Available at: http://www.quran-islam.org/articles/women_dress_code_(P1150).html
} 
ers, her responsibility will be reduced because the man has more responsibilities toward the women and to his family members. Due to the importance of women, Islamic law puts quotas or share from the money of parents and some relatives. Qur'an has explained in Surah Al-Nisa how should divide the inheritance between men and women, which depends on the women relationship with men.

1) Daughter:

a) If the daughter has brothers, then she will get or receive half from the inheritance, in accordance with Qur'an (Islam Holy Qur'an) ${ }^{26}$. In this case, I Islamic law gives men more (the double) than women due to the responsibility men to raise their family (his unmarried sister, parents, wife, and children), men also during the time of marriage should pay the money of bridal (the dowry). Hasan (1996: p. 18) confirmed that "women have no responsibility to raise their families, even their husbands".

b) If a family has no male children, which means they have only daughters (two or more), they will receive thirds of one's estate (Islam Holy Qur'an) ${ }^{27}$.

c) If the family has one daughter, she will receive half of what the parents leave.

2) Mother; mother has different provisions:

a) If the dead son has children, the mother will be equal to the father in the inheritance.

b) If the dead son has no children and no brothers and there are just parents, then the mother will receive one-third from her son's legacy.

c) f a dead son has brothers or sisters; the mother will receive a sixth.

3) Wife; the wife also has different provisions:

a) If the husband has no children, then the wife will receive one-fourth of his legacy.

b) If the husband has children, the wife will receive an eighth of what the husband leaves (Islam Holy Qur'an) ${ }^{28}$.

4) Sister;

a) If dead a man or woman has no ascendants (parents) or descendants (children) but has one brother or one sister, then for each one of them is a sixth.

b) If they are more than two (brothers and sisters), they will be shared in a third.

\section{- Polygamy ${ }^{29}$}

In the beginning, Islam has never imposed polygamy as a universal principle nor did not restrict the plurality of wives. In other words, Islam neither forcing Muslims to practice polygamy nor did not prohibit them from doing if certain conditions are fulfilled. Islam came at a time that has been the practice of here-

\footnotetext{
${ }^{26}$ Holy Qur'an, Surah Al-nisa, Verse (11).

${ }^{27}$ Holy Qur'an, Surah Al-Nisa'a, Verse (11).

${ }^{28}$ Holy Qur'an, Surah Al-Nisa, Verse (12).

${ }^{29}$ Polygamy is a practice of having two or more wives at the same time; whereas Polygamy is the practice of having two or more wives at the same time which Islam religion has permitted for the man to marry more than one wife and forbids the woman to marry more than one husband due to different reasons.
} 
ditary societies since pre-Islam the polygamy was just for fun and for the sake of leisure and pleasure (Yasin \& Jani, 2013). Yasin \& Jani (2013: p. 79) have explained that "polygamy in Islam is practiced as a way of providing means of protection not just for women who are widows and in need of protection and financial support, but also for those who are ill or barren." Polygamy was also well known to ancient times, such as; Egyptians, Greeks, Persians, Assyrians, Japanese, Hindus, Russians, Germanic peoples, the great Chinese Empire, and all previous religions polygamy. The old and new testaments are foremost in the list of the religious books that legalized and practiced it. Many of the Prophets before Mohammad entered into plural marriages, and in the new testament of the Bible, Jesus is commissioned to comply with and complete the Laws of Moses. Therefore, we cannot find a single quote in the Bible that forbids plural marriage. The prohibition of plural marriages in Christianity came about only due to legislation set forth specific segments of the Christian church and not by the original teachings of Christianity itself. To ensure polygamy is doing somewhat and to provide harmony to the society, Islamic law permits the man to marry more than one woman but has laid down certain conditions to control the free practice previously and take a more reasonable fair solution. Islamic law allowed the man to marry a maximum of four wives with strict justice and fairness in treatment. The husband must treat his wives fairly at the expense of living (place of living, drink, food, and clothing) and even in spend times. In the case man fears or has no money to support more than one wife inequality and justice, then he should remain monogamous, the Prophet Mohammad warned against favoritism ${ }^{30}$. However, Islamic law did not request equal treatment in emotions of the heart due to the reason that any person cannot control his feelings and emotions, as the man maybe can marry more than one wife, but he cannot love two women at the same time, Aisha, the Prophet Mohammad's wife narrated that (The Prophet of Allah would distribute everything justly among his wives, then say: O Allah! This is my division for what I possess, O Allah! Do not blame me for what you alone possess while I do not (i.e., emotions of the heart).

The primary purpose behind polygamy is to provide help for war widows and orphans, the reality saying that the number of men in any society inevitably decreases after the war. Polygamy provides the only decent solution for the widows and orphans left alone. In such circumstances when the women cannot find a breadwinner (especially uneducated) may resort to a monastic life which is unnatural or to an immoral and sinful life, in another side, Islam also strictly forbids sexual relations outside marriage, and polygamy is again the only decent and honest solution in cases where a man wants more than one partner (Al-Sheha, 2007).

On the other hand, Islamic law has given women a choice to continue married life or ask for a divorce, where a man cannot marry another woman without the permission or knowledge of the first wife. Besides, some reasons and circumstances push some men to marry more than one wife, which is con-

${ }^{30}$ Narrated -Abu Dawood (2133) and Tirmidhi (1141). 
sidered an excellent solution to solve some problems that leads to promiscuity, prostitution, or divorce. For instance, if the wife is sterile and the husband is interested in having children, and the husband cannot leave (divorce), he loves her. If a wife is chronically ill and cannot maintain her marital relations with her husband, should he keep her and take a second wife wherein she remains perfectly honored, cared for, and provided for by her husband, or should he divorce her ${ }^{31}$.

Moreover, some men are financially strong, sexually demanding, and potent with higher levels of hormonal testosterone. Sometimes one wife may not fulfill his lawful and natural sexual desire, which pushes the man to remain frustrated and pent up or seek unlawful sexual satisfaction outside the marriage and cause the family disintegration (Al-Sheha, 2007). In contrast, Islamic Law also forbids the man who seeks to marry more than one wife if he is unable to fulfill the essential requirement, and he knows for sure that he is financially incapable of supporting another wife and household because of its violation the justice and fairness in treatment between wives.

\section{Conclusion}

This paper found some differences in scope and application of human rights between international conventions and the Arab charter, which does not create a general state of dissonance in some issues such as religious freedom, the death penalty, and the equality between man and woman.

1) All international, regional conventions and the Arab Charter on Human Right (Islamic Law) are confirming that every person has the choice to choose a religion without any coercion, including freedom of thought, conscience, and religion. The person who has chosen convert to Islam must be in free will after getting to know about what Islam include of judgments and legal texts. Islamic law, like other religions, has the right to protect its principles by putting appropriate punishment. Muslims who want to change his or her religion and convert to another one will face the death penalty because Muslim scholars consider this act as treason where the treason in the legislation of all countries is one of the reasons that are causing the death penalty. The reality is saying it is seldom to find a Muslim person who wants to change or convert his or her to another religion because most Muslim people have chosen to convert to Islam with their free will and after getting to knowledge without any force or coercion.

2) In a case of the death penalty:

All international and regional conventions affirm that everyone has the right to life, and every state shall guarantee this right from the. The death penalty shall apply only for the most severe crimes following the laws in force at the time of the Commission of the crime and according to a final judgment rendered by a competent after the necessary conditions have been met for application (sen-

${ }^{31}$ See Suhaib Hasan, Ibid, at 16. The majority of families in Europe and America countries are suffering from the disintegration of the family members due to betrayals and the proliferation of illegal sexual relations between men and women. 
tence of death shall not be imposed for crimes committed by persons below eighteen years of age and shall not be carried out on pregnant women). Therefore, all countries are working to abolish the death penalty because they consider this punishment a violation of the right to life, while Islamic law considers this punishment a deterrent for violating and protecting every person's life, which there is no serious crime like the crime of murder. Islamic law insists on applying such punishment to preserve the human being's life because, in Islam, there is no serious crime like the crime of murder except killing by Mistake. The death penalty will stop the intention to kill another one, and all people, after getting knowledge the fate of every person who commits such a crime, they will stop even think to kill another one, so more, more knowledge between people about anyone who has any intent killing people where the death penalty will apply against to him. The criticism from Muslim scholars against those who want to abolish the death penalty, firstly, you should have to prevent the act before the crime rather than prevent the result after the act of crime. Islamic law did not violate the right to life; in all circumstances, Islamic law is pushing people (victim relatives) to forgive and take blood money or forgive the offender without taking anything.

3) In a case of the non-discrimination between gender:

All of international conventions affirm the equality between man and woman in all filed of life, no matter the positive discrimination due to their natural differences in physical, mental, emotional, and psychological qualities, inclinations, and abilities. Therefore, in its opinion, equality is in everything, which it is means the woman can do and get what she wants as the man did or got without any restrictions of the custom and culture where the woman will become more open than in past life. However, Islamic law considers that equality between men and women is possible and reasonable, the possible equality in the case of the ability to perform the duties and rituals of religion (commissioning and performing Islamic orders) which both man and woman must perform the obligations that imposed by the Islamic religion. The impossible equality is due to the women's natural differences in physical, mental, emotional, and psychological qualities, inclinations, and abilities. Some work that needs intensity, rigidity, and violence such as working in the public, army, police, and worker which women in these types of work have more mental, emotional, therefore there is no result or benefit for the women to join these works. In the previous Chapter III, we have seen the positive discrimination in Islamic law in a case of inheritance which Islam has given women half of the man for the above reason; in some circumstance give her the same as a man and maybe more than a man. In the case of the Hijab, every religion has its own belief and religious legislation. Like any other religion, Islam has its reason to impose the Hijab for Muslim women like Christian and Jewish. Finally, because of the multiplicity of cultures and traditions of peoples, there are many opinions about what citizens should enjoy human rights. It is impossible to impose on a country a strange culture and call it a 
violator of rights because they did not accept it, but we can find a compromise for the consensus of different opinions, such as dress and inheritance, which it should be as the habit of general peoples.

\section{Conflicts of Interest}

The authors declare no conflicts of interest regarding the publication of this paper.

\section{References}

Adebayo, M. (2001). Badekin-Modern Muslim States between Islamic Law and International Human Rights Law. PhD Thesis, Nottingham: The University of Nottingham.

Alalwani, T. J. (2012). Apostasy in Islam-A Historical and Scriptural Analysis. Herndon, VA: International Institute of Islamic Thought.

Ali Mohamed, A. Al. (2012). Implementation of Hudud (or Limits Ordained by Allah for Serious Crimes) in Malaysia. Selangor: International Islamic University Malaysia.

Al-Midan, M. A. (2007). Arab Charter on Human Rights 2004. Boston University International Law Journal, 24, 147-164.

Al-Sharafi, A. H. (2005). The Explanation of Yemen Law in the Crimes and Punishments. Sanaa: Sana'a University.

Al-Sheha, A.-R. (2007). Human Rights in Islam and Common Misconceptions. Conveying Islamic Message Society.

Arab Charter on Human Rights (2004).

Braybrooke, M. Religions and the Death Penalty, Amnesty International, British Section, at 1.

Eltayeb, \& Mohamed, S. M. (2001). A Human Rights Approach to Combating Religious Persecution: Cases from Pakistan, Saudi Arabia and Sudan. Antwerpen: Intersentia.

Ghassemi, G. (2009). Criminal Punishment in Islamic Societies: Empirical Study of Attitudes to Criminal Sentencing in Iran.

Ghormade, V. J. (2012). Analytical Framework of the Protection of Human Right under the Arab Charter on Human Rights (2004). https://doi.org/10.2139/ssrn.2000043

Hasan, S. (1996). The Rights and Duties of Women in Islam.

Hood, R. (2006). The Enigma of the "Most Serious" Offences, Centre for Human Rights and Global Justice Working Paper Extrajudicial Executions Series (Number 9 2006). New York: NYU School of Law.

IBAHRI Resolution (2008). The Death Penalty under International Law. A Background Paper, London: International Bar Association Press.

International Covenant on Civil and Political Rights (1966).

Islam Holy Qur'an.

Natan, L. (2000). Religion, Beliefs, and International Human Rights. New York: Orbis Books.

Partsch, K. J. (1981). Freedom of Conscience and Expression, and Political Freedoms.

The Amnesty International Reports.

http://www.amnestyusa.org/research/reports/death-sentences-and-executions

The Convention on the Elimination of all Forms of Discrimination against Women.

The Higher Committee of Human Rights (2014). Woman's Rights Are Human Rights. 
United Nations Publication.

The Higher Education Academic (2011). An Introduction to Islamic Criminal Justice-A Teaching and Learning Manual UKCLE.

Universal Declaration of Human Rights (UDHR) (1948).

Yasin, R. F. B. F., \& Jani, M. S. (2013). The Positive Role of Polygamy in Reducing Women Socio-Related Problems in Malaysia. American International Journal of Social Science, 2, 72. 